\title{
Students' Perception of the Effects of Online Social Networking: An Empirical Assessment
}

\author{
S.M. Asif-Ur-Rahman ${ }^{1,}$, Mohammed Junayed $^{2, b}$ \\ and Muhammad Rehan Masoom ${ }^{3, c^{*}}$
}

${ }^{1}$ Assistant Professor, School of Business \& Economics, United International University, Bangladesh

\author{
${ }^{2}$ Undergrad Student, School of Business \& Economics, United International University, Bangladesh \\ ${ }^{3}$ Assistant Professor, School of Business \& Economics, United International University, \\ Bangladesh \\ E-mail address: aasifrazib@yahoo.com, ’m.junayed@gmail.com, crehan_1611@yahoo.com
}

Keywords: Social Networking sites, Perception, Usage of social networking, CGPA, Study-habit

\begin{abstract}
Social networking sites have had an impact on the twenty-first century generations of internet user, making it a very active means of communications, particularly among university students. Questions arise about the impact of social networking sites on academic performance and the possibility of using them as an effective educational tool to improve academic performance. The study assesses students' opinion regarding usage of social networking sites and its impact on their academic performance. Non-probability convenience sampling technique was used to select a sample of ninety-six undergraduate students from seven private universities and they were asked to complete a structured questionnaire set with 18 questions. Descriptive-comparative research design was adopted. The data was subjected to descriptive analysis, particularly percentages and frequency table counts.
\end{abstract}

\section{INTRODUCTION}

Millions of people generally use social networking sites on a regular basis across the globe for different reasons. A big portion of social network users is made up of youths where most of them are college or university students. In recent times, online social networking sites engage students significantly. This engagement is not merely limited to as sources of information only, and hence needs to be studied. The internet itself has been changed as a medium of communication with growth in its multifarious applications. Particularly the interactive nature of the online environment has been functional in expanding social networks. Although connecting through social networks began as merely a niche activity, with time, it now has become a regular phenomenon. The social networking sites are now being used in various ways, ranging from forming communities, chatting, blogging, reaching out to close friends or relatives, to collecting information for research and so on. In addition, numerous institutions are formally forming number of groups or communities on various social networking sites.

The purpose of this research is to determine the perception of the impact of the social networking sites on the academic performance of students. The objective of this research is to discover whether there is any impact assessed by the students related to the effect of spending time on social networking sites on the academic performance of university students. Hence, the research questions include: (a) do students belief that the use of social media sites has any impact on university students' academic performance, (b) what are the benefits they see (if any), when they engage themselves in social networking, and (c) why do student visit their social networking sites.

People of Bangladesh use various kinds of Social Networking Sites on the internet and this study seeks to advice on how the Social Networking Sites can be fully utilized and used as a platform for knowledge and education. The finding of this research hopefully will create an 
awareness among university students accessing social networking sites. Therefore, the primary reason of this research is to determine whether social networking sites affect the academic performance of university students and make sure that social networking site would not negatively affect students' academic performance.

\section{LITERATURE REVIEW}

Social networking can be defined as the "...collection of internet websites, services, and practices that support collaboration, community building, participation, and sharing" (R. Junco, G. Heiberger \& E. Loken, 2010). The term "networking" gives emphasis to relationship initiation between the strangers, (NB Ellison, C Steinfield \& C Lampe, 2007). Hence, the prime activity of Social Networking Sites users is to form social relations and/or maintain it. Twitter, MySpace, Facebook, and Google+ are the most prominent examples of social networking sites. The everincreasing usability and the growing popularity of these sites over the past several years made it an international concern for the academicians and the practitioners as well. These sites are frighteningly popular among the students of college and undergrad level. A recent survey of three thousand students from across the United States shows that ninety percent of college students use Facebook and thirty-seven percent use twitter (Eden Dahlstrom, To de Boor, Peter Grunwald \& Martha Vockley, 2011). It is a way to form association and establish connection not only on campus, but also with friends and close acquaintances that are staying outside of school. Further, due to the increased popularity of such sites, experts and professors are calling into question of whether grades of students are being affected by spending longer period on social media (Choney, 2010). It is often argued, that the social media negatively affects students' GPA, and the amount of time they spend preparing for their classes (R. Junco, G. Heiberger \& E. Loken, 2010). One explanation for such an impact is that social media provides excessive level of stimulation that distract the students and hamper the level of concentration, hence put a hindrance to complete their coursework (Rithika M. \& Sara Selvaraj, 2013).

Social network sites were initially established to facilitate interaction among them who have similar fields of interest. Therefore, social networking is being used mostly for interacting with people within the institute, and beyond it, depending upon the area of interest (Danah M.Boyd \& Nicole B. Ellison, 2007). However, regarding the standard undergraduate course of instruction, in which the instructor's goal is to make a captivation ambience that boosts inscrutable learning, throughout the course session, very often than not, many students are on Facebook rather than following the lecture (Waleed Mugahed Al-rahmi, Mohd Shahizan Othman \& Mahdi Alhaji Musa, 2014). Thus, the use of the internet as such, can be considered as a factor that can influence students' performance positively or adversely (Saba Mehmood \& Tarang Taswir, 2013). The majority of Social Networking Sites users are of tender aged, commonly the students in higher education, and they are often regarded as the 'Digital Natives'(Prensky, 2010). Their chief purpose of using the Social Networking Sites is to stay in touch with their friends, and bolster existing connections rather than forming a new one (NB Ellison, C Steinfield \& C Lampe, 2007). This usance exposed the potentiality for Social Networking Sites to comprise a medium for online learning. It would be a valuable and convenient e-learning platform if the activenesses of e-learning could be properly incorporated into the lineaments of Social Networking Sites. (JUANG, 2010).

Collaboration through social media affirms several constructivist approach to learning, where both the students and educators can work collectively to co-create understanding of a specific issue, instead of an approach that stresses separate contributions (Stevens, 2009). For that, students and educators can become equal participants in the knowledge sharing process. Although this seems beneficial for creating and disseminating knowledge, social media can also become a privacy concern, such as cyber-plagiarism and cyber-bullying (Baiyun Chen \& Thomas Bryer, 2012; Fryea, Elizabeth M., Woodrow Trathena \& David A. Koppenhavera, 2010; Jackson, 2011; Joanne Smailesa and Pat Gannon-Leary, 2011). This indicates that constituting standards for social media 
usage ought to include code of conduct and attitude guidelines similar to those implemented in the classroom.

Researchers like Choney (2010), San Miguel (2009) and Enriquez (2010) shows that students' use of the social media sites and level of academic performance are inversely related. Nielsen Media Research study conducted in June 2010 stated that almost one-fourth of the students spend their valuable time on the internet, in general, and on social networking sites in particular (Wade C. Jacobsen, B.S., and Renata Forste, 2011). The American Educational Research Association conducted a research and clearly mentioned that social media users study less and generate lower grade (Abaleta, A. B, Centaza, S.M, \& Calimlim, M. E, 2004). Further, friendship networks oftentimes demand access to information and knowledge directly and indirectly, and impressions of friendly relationship webs on student academic performance are already affirmed (TT Baldwin, MD Bedell \& JL Johnson, 1997). A student's adherence in actions such as making acquaintances on Social Networking Sites need to be seen as students bearing access to crucial information. This can be conveyed toward improving the students' academic performance. It has been analyzed that cyberspace use for educational activities and some pertinent task such as online tutorials, online lectures and training material downloading are beneficial. However, using internet for only social networking is, indeed, useless and perhaps dangerous as well. Thus, the pros and cons of networking sites in reality, depends on the ability and willingness of the concerned individual, of whether they would be able to harness the opportunity, as well as have the capacity to cope with academic performances. (K Banquil, C Burce, N Chua \& S Dianalan, 2009).

\section{METHOD}

Descriptive-comparative research design was adopted and the data was collected with the help of a questionnaire in a survey. In this research, the data was collected using a method of survey questionnaire which was distributed among students using Google Form. Seven academic institutions were used to select respondents from -United International University, North-South University, South-east University, Brac University, East-West University, University of Liberal Arts Bangladesh (ULAB), and American International University (AIUB).The data was subjected to descriptive analysis, particularly percentages and frequency table counts.

In this research, convenience-sampling technique was used to select the universities and ninety-six undergraduate students fully completed questionnaires. The age-range of respondents was under 18 to 25 years. Different types of tools such as five-point Likert scale, check box, multiple -choice and dichotomous scales were used in this study. A questionnaireconsisting of 18 items was designed and distributed. The questionnaire was composed of two parts, namely, Part I containing the respondents' personal data such as age, gender, semester and department. In addition, Part II - contained the questions for analyzing students' perception regarding impact of social networking sites. The questions were formulated on the basis of readings in relevant theses, journal articles, and magazines as well as interview with experts. The data was subjected to descriptive analysis, particularly percentage and frequency table counts, and Microsoft Excel was used to analyze the data.

\section{FINDINGS \& DISCUSSIONS}

The questionnaire starts with demographic questions, finding age, gender, academic performance. The responses showed that 45.1 percent of those who participated are male while 54.9percent are female. 


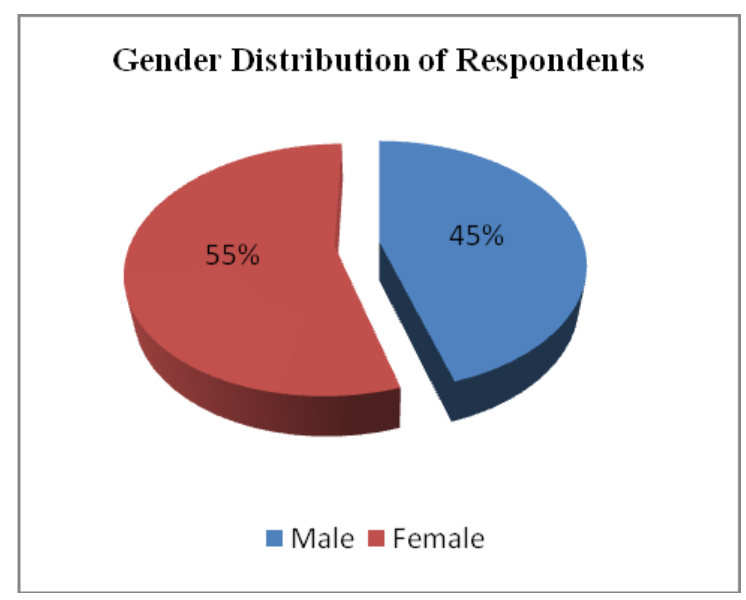

Fig 1. Gender Distribution of Respondent

Age group of those who participated in the survey are from less than 18 years old 1.2 percent , $18-21$ old 50 percent , $22-25$ year and above 48.8 percent .

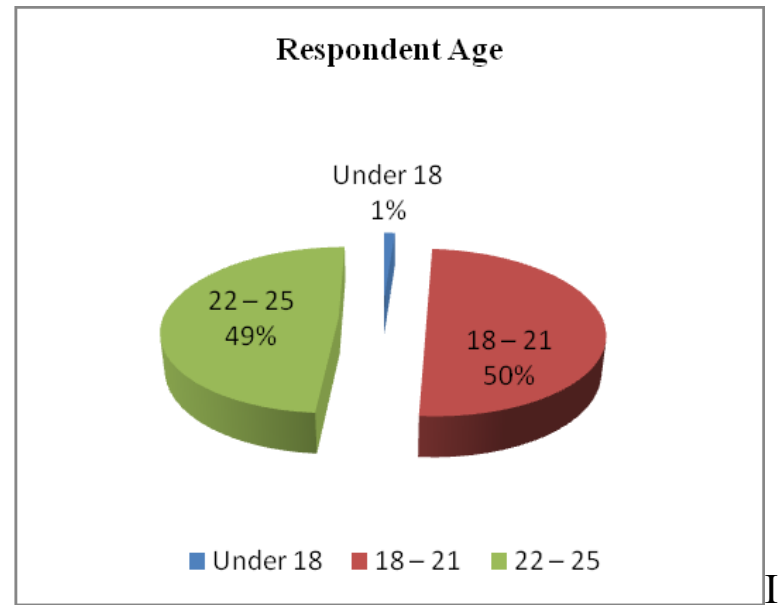

Fig 2. Respondents Age

- Effect of social network sites in your teaching and learning

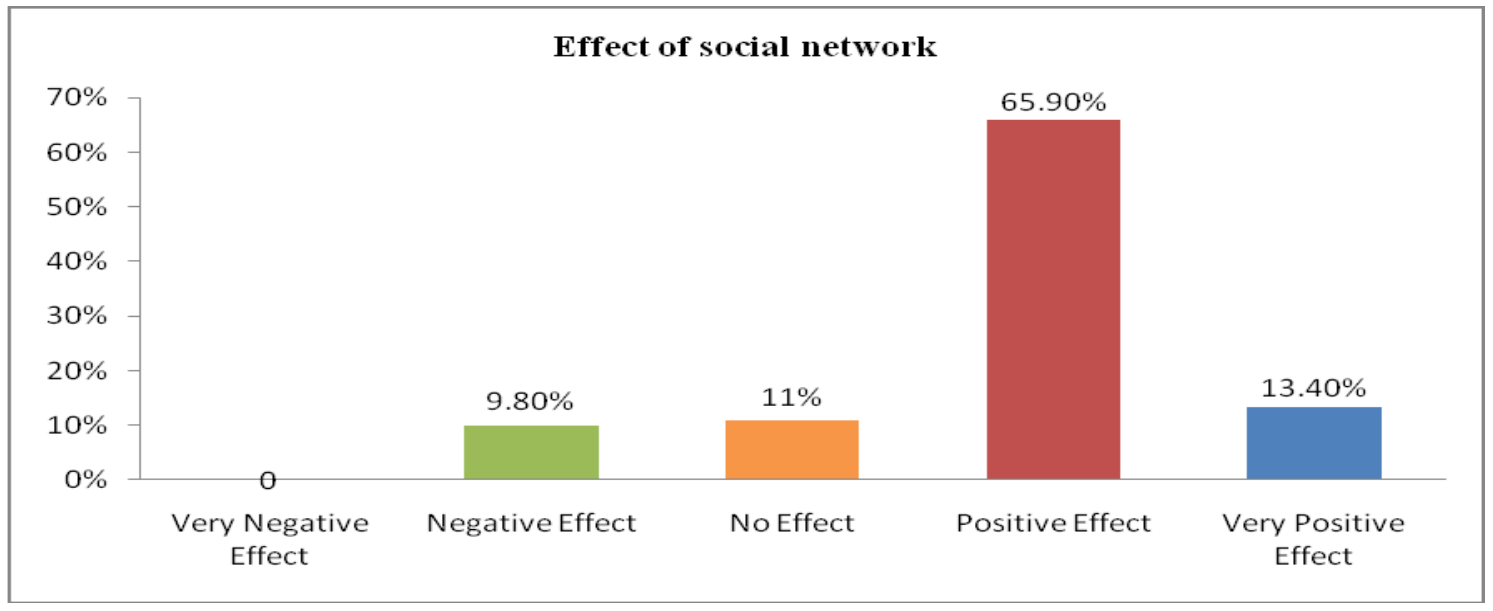

Fig 3. Effect of social network

The study shows that 65.9 percent of undergraduate students from seven universities agreed that social networking sites have positive effect on their studies. Only 9.8 percent of the students reported facing negative effect. From the analysis the researchers conclude that social networking 
sites are one of the fastest ways information is shared, however it has caused negative effect to some extent to those addicted to it.

- Do you use social network for academic purposes

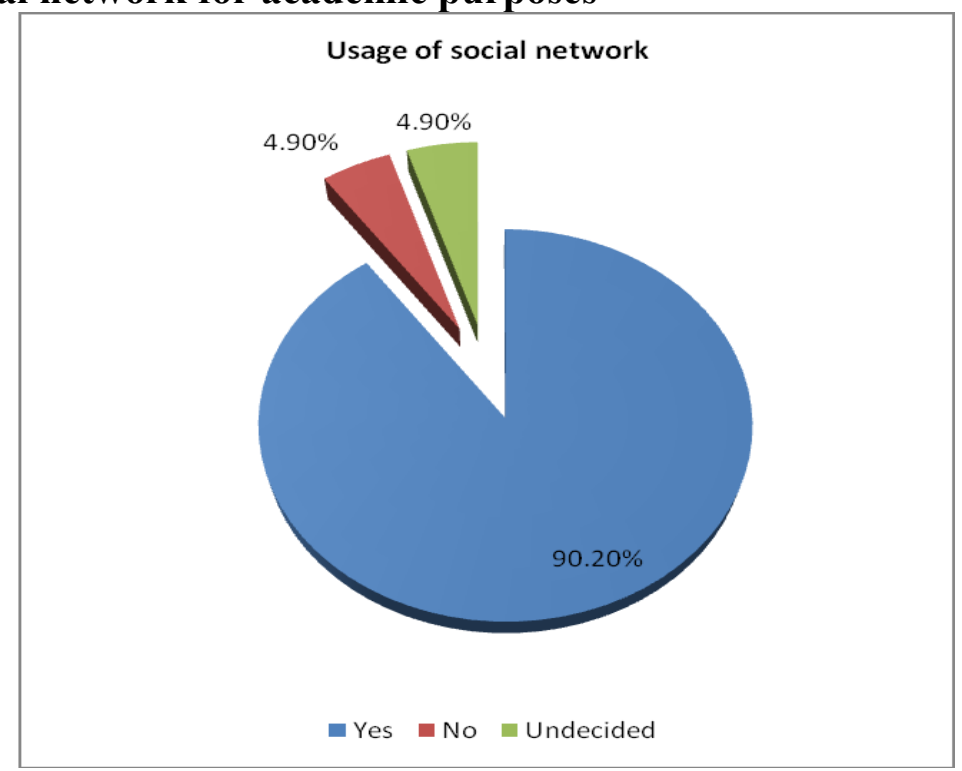

Fig 4. Usage of social network

Findings indicate that undergraduate students in the seven universities paved together 90.2 percent of the students use social networking sites for academic purposes. In addition, only 4.9 percent do not use it for academic purposes and another 4.9 percent students still on undecided stage of social networking sites. This proves that a large number of students use social networking sites for academic purposes.

- In which sectors do social networks help you

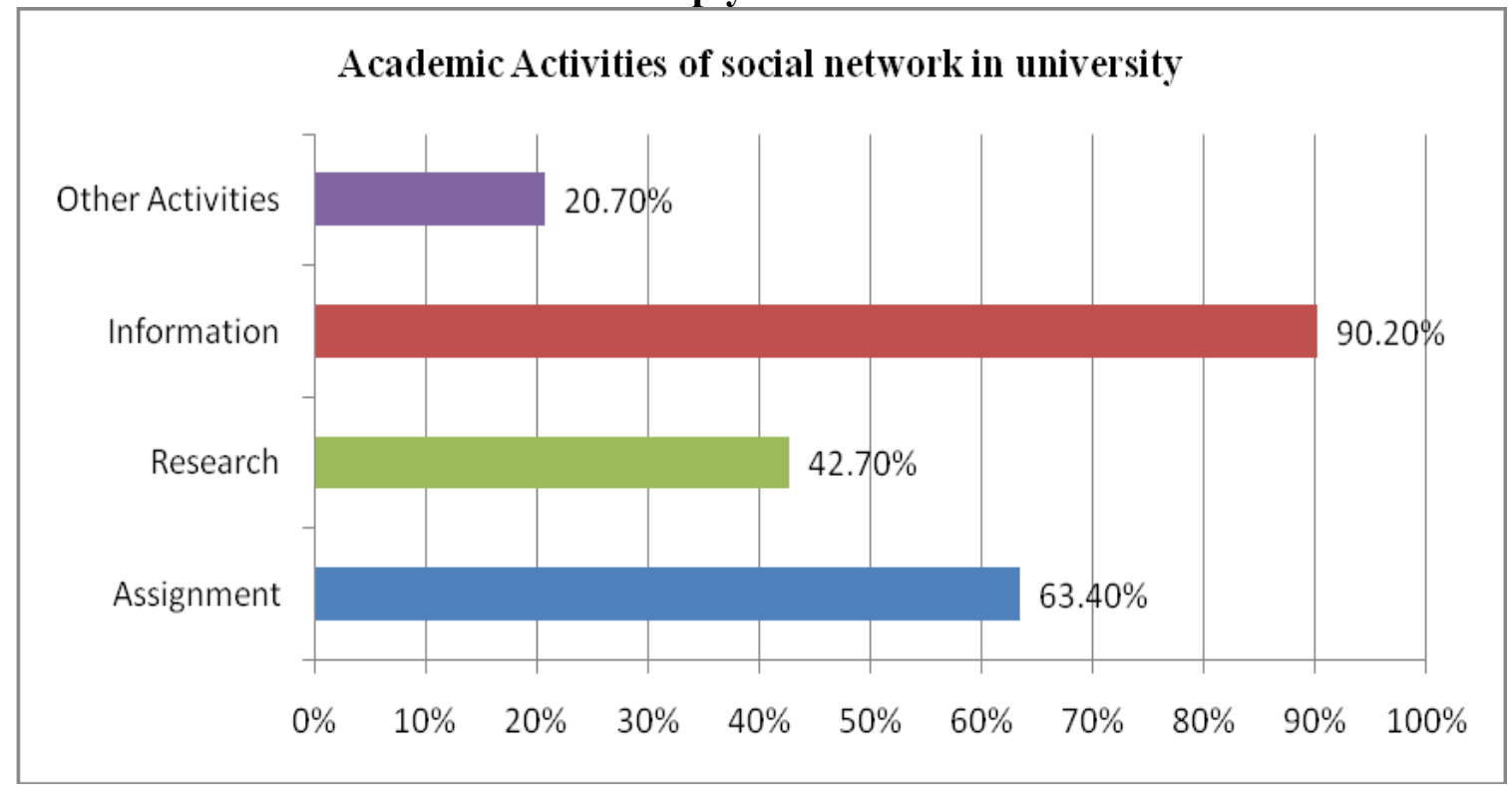

Figure 5: Academic Activities of social network in university

Analysis shows that 90.20 percent undergraduates of the seven universities said social networking sites help them for general information, for assignment 63.40 percent and for research 42.70 percent. However, only 20.70 percent use it for other activities. 
- Social Networking sites always used by university students in Bangladesh

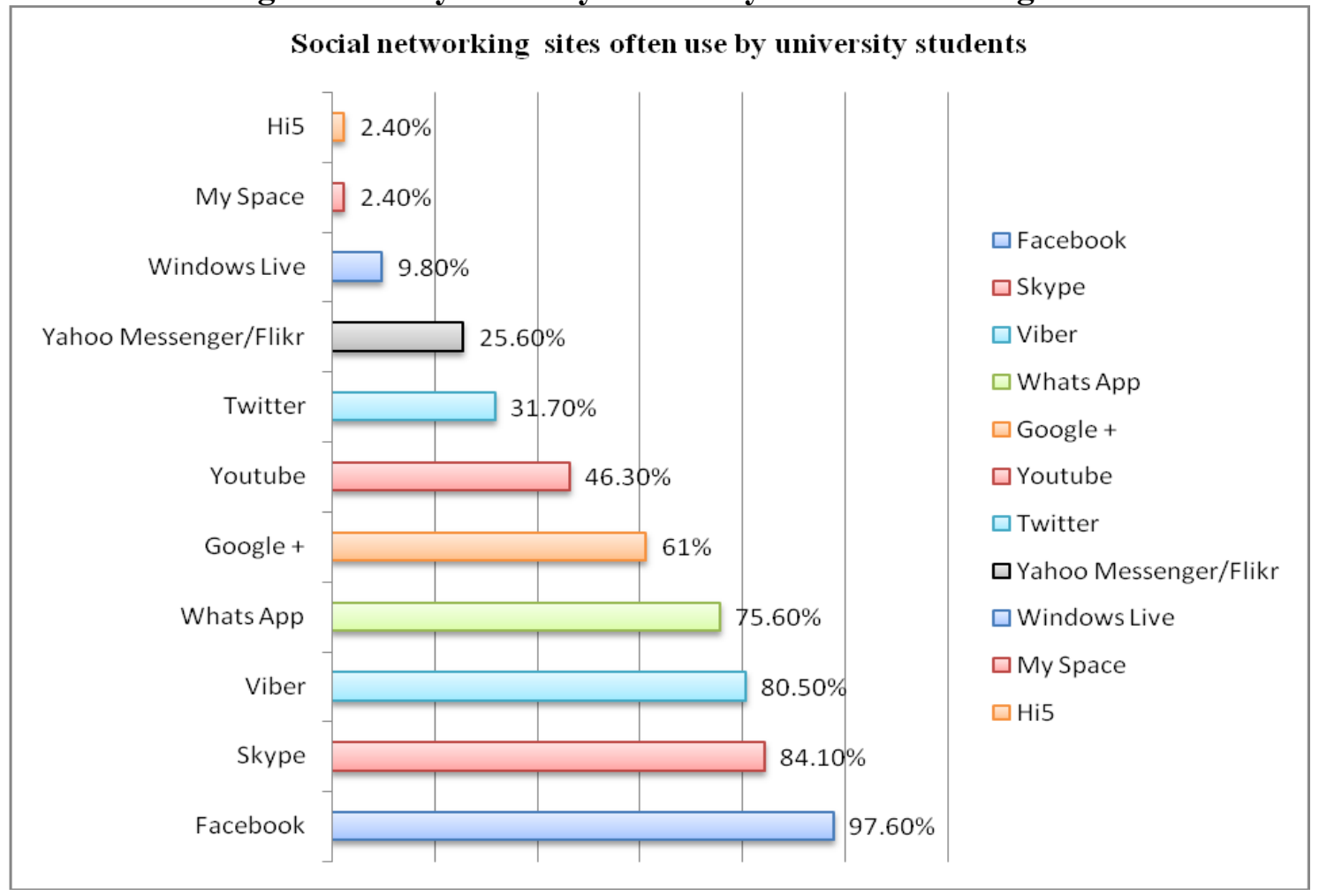

Fig 6. Social networking sites often use by university students

The study indicates the extent of students' usage of popular social networking sites - Facebook 97.6, Skype 84.1 percent, Viber 80.5 percent, Whats app 75.6 percent ,Google+ 61 percent, Youtube 46.3 percent, Twitter 31.70 percent, Yahoo Messenger/Flikr 25.60 percent, while Windows Live,My Space and Hi5 were not that much commonplace to students.

- How much time do you spend daily in social network activities?

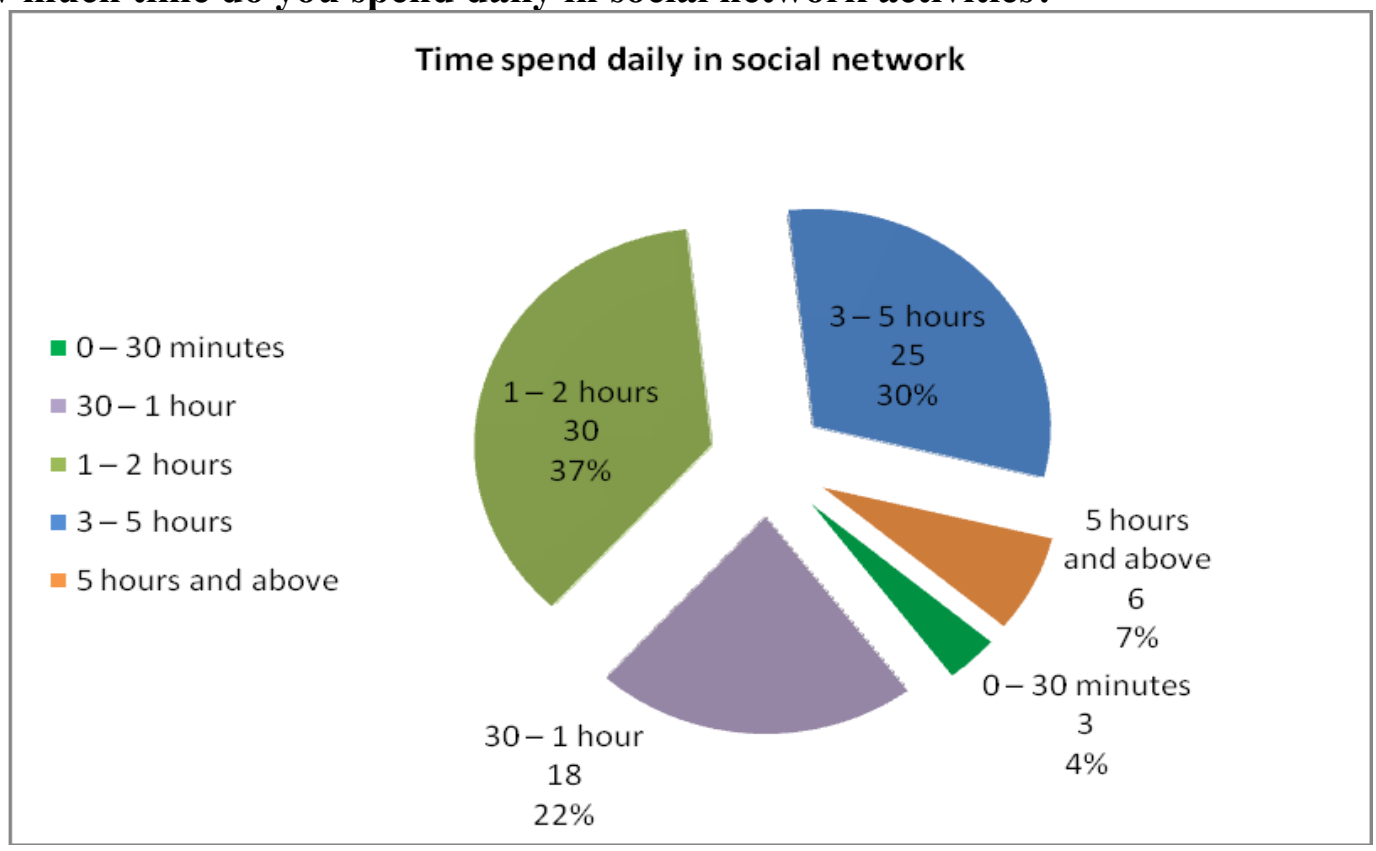

Fig 7. Time spend daily in social network

It is found that 7.3 percentundergraduates spent close to five hour and above per day in social networking sites, 36.5 percent of them spent one to two hours in social networking activities. Some students (3.7 percent) spent 0 - 30 minute and others (30.5 percent) spent $3-5$ hours. 
- $\quad$ Reasons for social networking sites usage by undergraduates

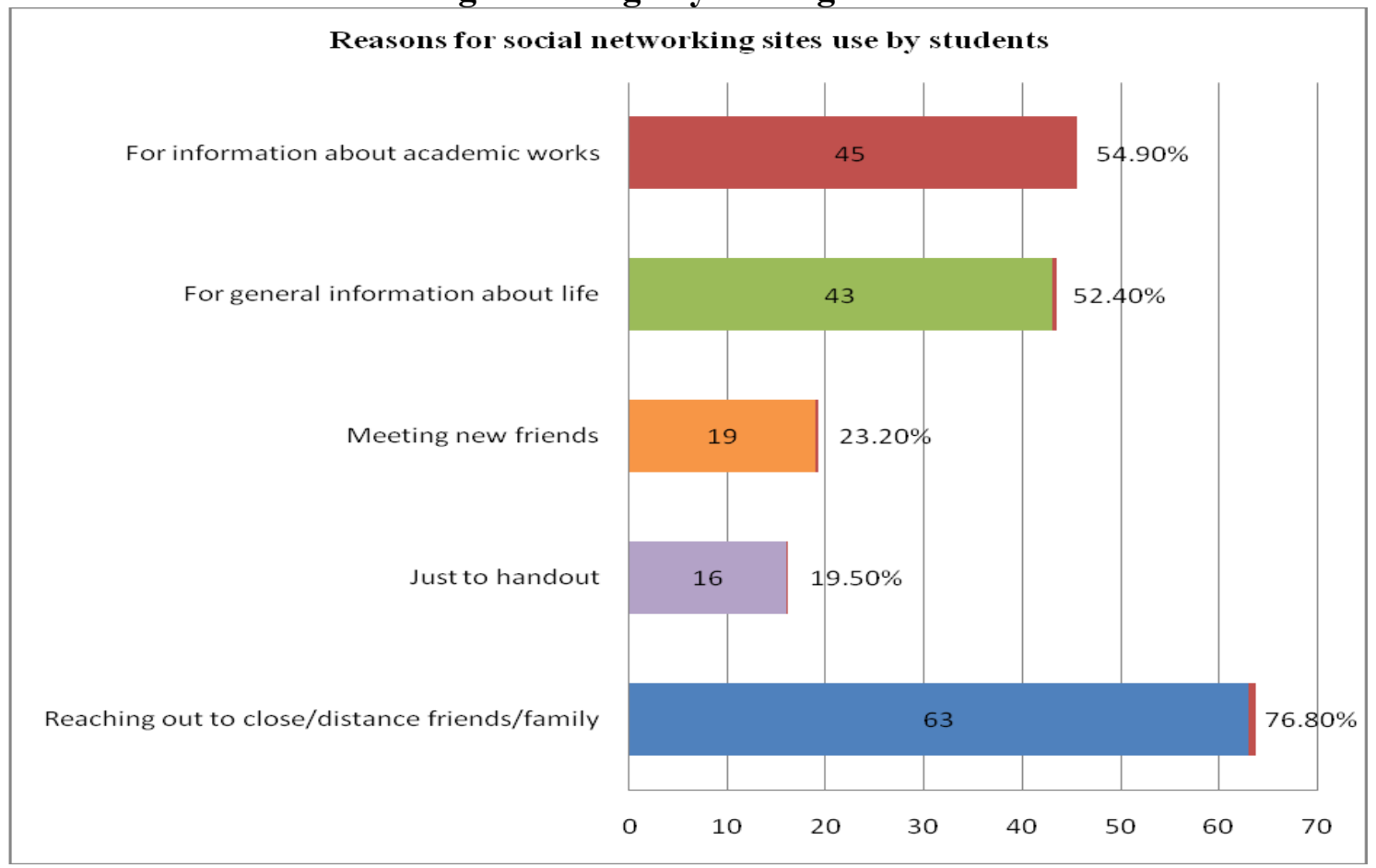

Fig 8. Reasons for social networking sites usage by undergraduate

Findings show that the majority of the respondents ( 76.8 percent) use social networking sites for reaching out to friends/family, for collecting or sharing information about life (52.4 percent), for sharing information about academic works (54.9 percent), for meeting new friends (23.2 percent) and just for hanging out(19.5 percent). This showed that undergraduates in the seven universities use social networking sites for reaching out to friends/family and for information about academic activities.

- Social networking sites have had an effect on grades or performance.

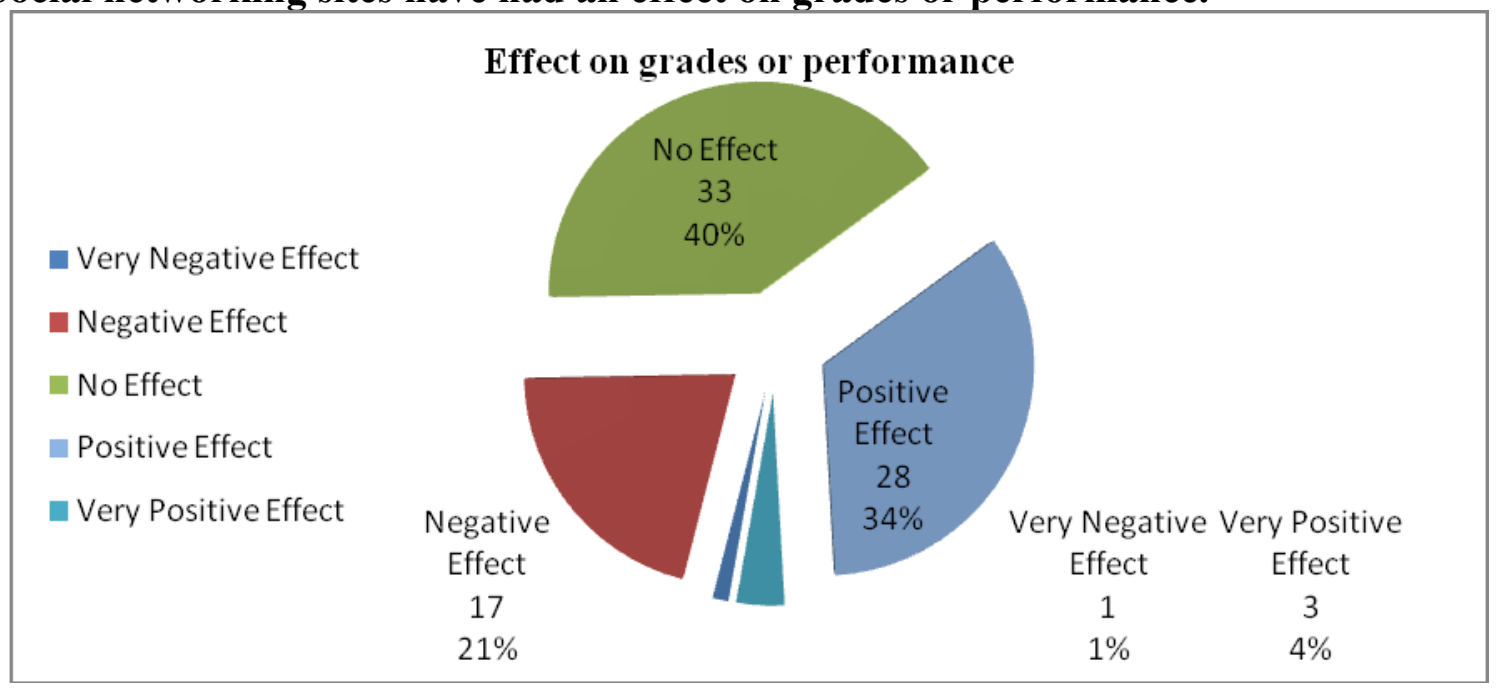

Fig 9. Effect on grades or performance

When respondents were asked whether the social networking sites had an effect on their grades or academic performance, 34.1 percent answered in the positive way while 20.7 percent gave negative responses. It was found surprisingly from the analysis that majority of the respondents (40.2 percent) confirmed that the use of social networking sites had no effect at all on their grades or academic performance. 


\section{- Academic performance - Cumulative Grade Point Average (CGPA)}

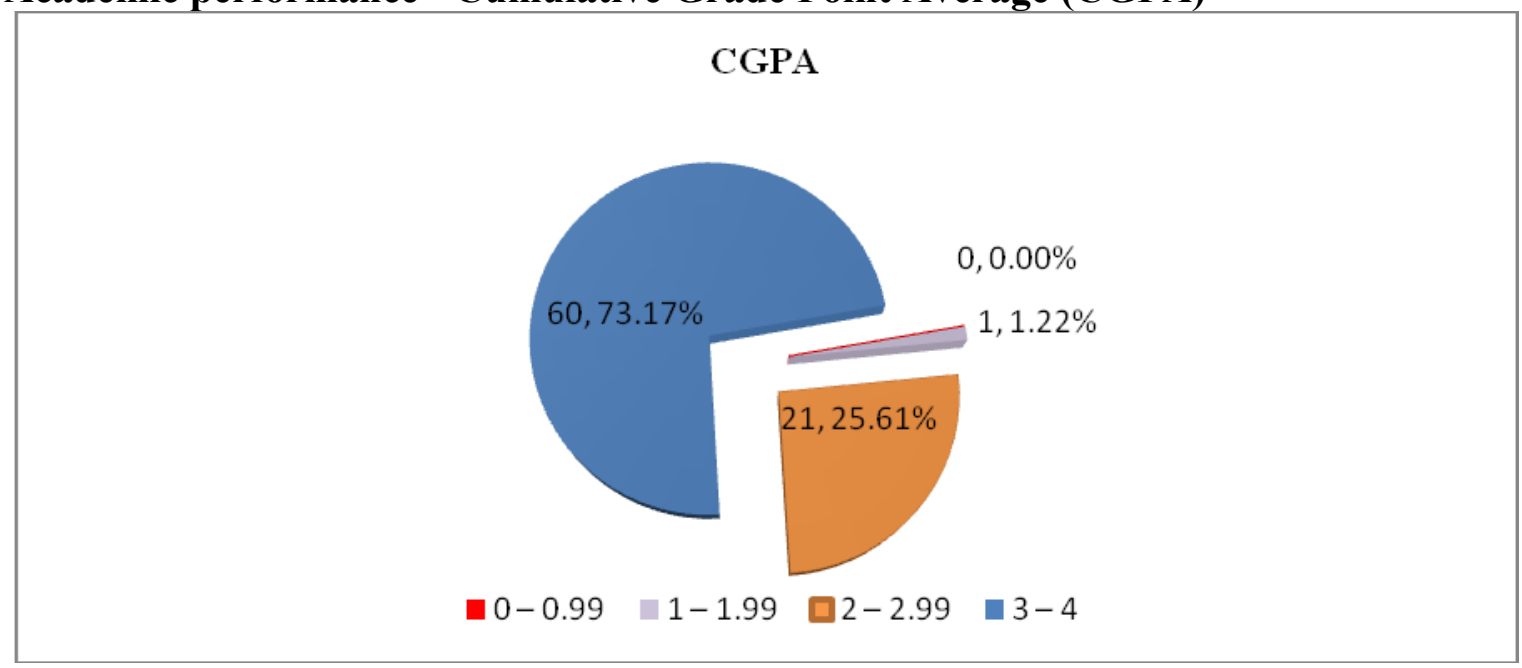

Fig 10. Academic performance - Cumulative Grade Point Average (CGPA)

The study indicates that among the undergraduate students of the select universities, 73.2 percent had a reasonably high academic performance while 25.6 percent perform moderately and only 1.2 percent had a rather poor performance. The results imply that students using social networking sites show high academic performance.

- Do you think your educational institution uses social network sites well?

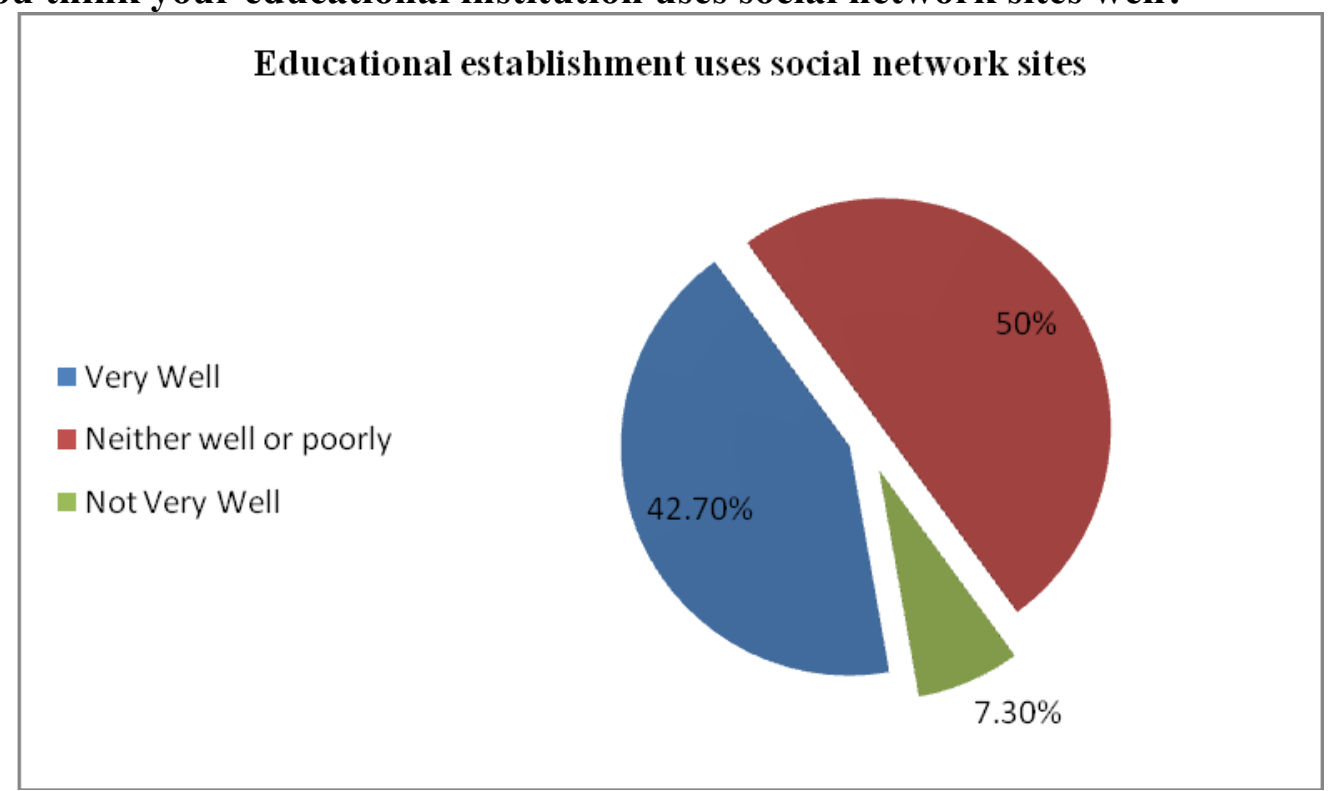

Fig 11. Effects of educational institutions using social network sites

It is found that while most students used social networking sites for educational purposes, only 42.7 percent said they were benefited by their educational institutions using social networking facilities. Fifty percent students were still undecided while 7.3 percent students found social networking sites not helpful in their educational establishment.

\section{IMPLICATIONS FOR FURTHER STUDIES}

This study on effects of social networking sites on university students' academic performance was centralistic in nature. Further studies can be done in more specific subject areas to see whether usage of social networking could have varied impacts on students' academic achievement. 


\section{CONCLUSION}

The researchers found that students spend no less than thirty minutes a day browsing through social networking sites. However, most of the respondents do feel that social networking sites have positive impact on their academic performance, because social networking sites can be used for various academic activities such as communication with faculty members and university authorities, discussing academic topics with classmates and assignment purposes. On the other hand, the negative impacts of social networking sites on their academic performance are considerably low. The social networks, if designed and modified to the specific educational needs of each student, related to each major in communication, can be useful instruments in improving academic performance of undergraduate students.

\section{References}

[1] Abaleta, A. B, Centaza, S.M, \& Calimlim, M. E. (2004). Impact of Social Networking on the Academic Performance of College Students in Anellano University-(Unpublished Dissertation). 1-19.

[2] AC Karpinski 7 A Duberstein. (2009). A Description of Facebook Use and Academic Performance among Undergraduate and Graduate Students. San Diego, California: American National ResearchAssociation, pp 1-19.

[3] Baiyun Chen \& Thomas Bryer. (2012). Investigating instructional strategies for using social media in formal and informal learning. International Review of Research in Open and Distan, 13(1) p 84-104.

[4] Benzie, R. (2007). Face book banned for Ontario staffers. Retrieved from The Star: www.thestar.com/news/2007/05/03/facebook_banned_for_ontario_staffers.html

[5] Choney, S. (2010). Retrieved from

http://www.nbcnews.com: http://www.msnbc.com/id/39038581/ns.technology_and_sciencetech_and_gadgets

[6] Eszter Hargittai \& Yu-li Patrick Hsieh. (2010). Predictors and Consequences of Differentiated Practices on Social NetworkSites. Information, Communication \& Society, 13(4), pp. 515536.

[7] Fryea,Elizabeth M., Woodrow Trathena \& David A. Koppenhavera. (2010). Internet workshop and blog publishing: Meeting. The Social Studies, Vol 101, Issue 2, p 46-53.

[8] Ishfaq Ahmed. \& Tehmina Fiaz Qazi. (2011). A look out for academic impacts of Social networking sites (SNSs): A student based perspective. African Journal of Business Management, 5(12), pp. 5022-5031.

[9] Jackson, C. (2011). Your students love social media...and so you can. Retrieved from Teaching Tolerance:

http://www.tolerance.org/magazine/number-39-spring-2011/feature/your-students-lovesocial-media-and-so-can-you

[10] JL Martin \& KT Yeung. (2006). Persistence of close personal ties over a 12-year period. Social Networks , 28,pp 331-362.

[11] Joanne Smailesa and Pat Gannon-Leary. (2011). Peer mentoring-is a virtual form of support a viable alternative? Research in Learning Technology, Vol 19(2), p 129-142.

[12] JUANG, Y.-R. (2010). Integrating social networking site into teaching and learning. Proceedings of the 18th International Conference on Computers in Education. Putrajaya, Malaysia, p244-251. 
[13] K Banquil, C Burce, N Chua \& S Dianalan. (2009). Social networking sites affect one's academic performance adversely. Retrieved from

http://www.scribd.com/doc/28919575/SOCIAL-NETWORKING-SITES-AFFECT-ONE-SACADEMIC-PERFORMANCE-ADVERSELY

[14] Miguel, R. S. (2010). Study on Facebook and Grades Becomes Learning Experience for Researcher. Retrieved from TechNews:

/www.technewsworld.com/rsstory/66805.html?wlc=1286985671\&wlc=1287195471

[15] NB Ellison, C Steinfield \& C Lampe. (2007). The benefits of Facebook "Friends": Social capital and college students' use of online social network sites. Journal of Computer-Mediated Communication, 12(4), pp1143-1168.

[16] Okereke, C. Ebele, Lucky U. Oghenetega. (n.d.). The Impact of Social Media on the Academic Performance of University Students in Nigeria. Retrieved from http://www.iiste.org/Journals/index.php/JEP/article/view/16971

[17] Prensky, M. (2010). Digital natives, digital immigrants. Retrieved from On the Horizon: www.nnstoy.org/download/technology/Digital percent 20Natives percent 20 percent 20Digital percent 20Immigrants.pdf.

[18] R. Junco, G. Heiberger \& E. Loken. (2010). The effect of Twitter on college student engagement and grades. Journal of Computer Assisted Learning, pp1-14.

[19] Rithika M. \& Sara Selvaraj. (2013). Impact of social media on student's academic performance. International Journal of Logistics \& Supply Chain Management Perspectives , Vol 2, No 4.

[20] Saba Mehmood \& Tarang Taswir. (2013). The Effects of Social Networking Sites on the Acade. International Journal of Arts and Commerce, Vol. 2 No. 1.

[21] Sheldon, P. (2008). STUDENT FAVORITE: FACEBOOK AND MOTIVES FOR ITS USE. Southwestern Mass Communication Journal, Journal, 23(2), pp. 39-53.

[22] Stevens, V. (2009). Modeling social media in groups, communities, and networks. Tesl-Ej , 13(3) p 1-16.

[23] TA Pempek, YA Yermolayeva \& SL Calvert. (2009). College students' social networking experiences on facebook. Journal of Applied Development psychology, 30(3),227-238.

[24] TT Baldwin, MD Bedell \& JL Johnson. (1997). Network effects on student satisfaction and performance. Academy of management journal , 40.6 (1997): 1369-1397.

[25] Wade C. Jacobsen, B.S., and Renata Forste. (2011). The Wired Generation: Academic and Social Outcomes of Electronic Media Use Among University Students. Cyber Psychology Behaviour \& SocialNetworking , 18,(5) pp.6, 275-285. 